\title{
Trgovački centri i promjene u gradskoj jezgri: slučaj Zadra
}

\author{
Željka Tonković \\ Odjel za sociologiju Sveučilišta u Zadru, Zadar, Hrvatska \\ e-mail: zeljka.tonkovic@unizd.hr
}

\begin{abstract}
SAŽETAK Trgovački centri specifičan su proizvod i simbol potrošačkog društva i kulture, a njihova je pojava bila jedan od najvidljivijih znakova transformacije postsocijalističkih gradova. Namjera ovog rada ukazati je na povezanost procesa decentralizacije i suburbanizacije trgovine s promjenama u zadarskoj gradskoj jezgri. Prvi cilj istraživanja bio je utvrditi stanje zadarske povijesne jezgre s obzirom na njezine komercijalne, poslovne i turističke funkcije. Kako bi se ustanovila zastupljenost pojedinih tipova sadržaja, provedeno je terensko istraživanje kojim su popisani i kategorizirani poslovni prostori unutar povijesne gradske jezgre. Drugi cilj istraživanja bio je ispitati kako različiti tipovi aktera koji su profesionalno vezani za prostor povijesne jezgre percipiraju njezino trenutno stanje te kako vide glavne smjernice revitalizacije. U tu svrhu provedeno je kvalitativno istraživanje. Na temelju istraživačkih nalaza u radu se razmatraju promjene koje se odvijaju u zadarskoj povijesnoj jezgri kao i opće smjernice revitalizacije.
\end{abstract}

Ključne riječi: trgovački centri, povijesna jezgra, javni prostor, revitalizacija, Zadar.

\section{Uvod}

Fenomen trgovačkih centara usko je povezan s usponom „potrošačkog društva“1, odnosno „potrošačke kulture“2 i konzumerizma33 (Featherstone, 1991.; Lipovetsky,

1 „Potrošačko društvo naziv je kojim se izražavaju neka svojstva suvremenog masovnoga kapitalističkoga i tržišnoga društva, društvenog djelovanja pojedinaca i skupina te načina ponašanja u kojima je potrošnja postala dominantna društvena vrijednost, a tržišni odnosi prevladavajući društveni odnosi“ (Peračković, 2013.:35).

2 „Potrošačka kultura podrazumijeva da se u modernom svijetu, osnovne društvene prakse i kulturne vrijednosti, ideje, aspiracije i identiteti definiraju i usmjeravaju prema potrošnji, a ne drugim društvenim dimenzijama" (Čolić, 2008.:958).

3 Kao kompleksan društveni i kulturni fenomen, konzumerizam nadilazi sam čin potrošnje, odnosno prakse kupovanja te se može razumjeti kao „kulturni izraz i manifestacija sveprisutnoga čina potrošnje“ (Čolić, 2008.:969). Drugim riječima, konzumerizam predstavlja „psihosocijalni izražaj presijecanja između strukturalnog i individualnog u sferi potrošnje. Iskustvo potrošnje jest psihosocijalno, u smislu da predstavlja most koji povezuje pojedinca i društvo" (Miles, 2006.:45, prema Čolić, 2008.:969). Pojedini autori stoga govore o konzumerizmu kao životnom stilu. 
2008.; Hromadžić, 2008.). Prethodna istraživanja trgovačkih centara u Hrvatskoj bavila su se geografskim aspektima njihova razvoja (npr. Lukić i Jakovčić, 2004.), socijalnim i drugim funkcijama (npr. Jakovčić i Rendulić, 2008.; Lukić, 2002.) te odnosom trgovačkih centara i javnih prostora u središtima hrvatskih gradova (Zlatar, 2013.; Zlatar, 2011.; Šimić, 2010.). Namjera ovog rada ukazati je na povezanost procesa decentralizacije i suburbanizacije trgovine s promjenama koje se odvijaju u zadarskoj gradskoj jezgri.

U globaliziranom potrošačkom kapitalizmu procesi potrošnje zadobivaju vodeću ulogu u restrukturiranju gradova, zbog čega njihova vitalnost i prepoznatljivost uvelike ovise o sposobnosti stvaranja i održavanja predodžbe o gradu kao mjestu privlačnom za potrošnju, uključujući i turističku potrošnju (Jayne, 2006.; Urry, 1995.). Utjecaji potrošačke kulture na urbane prostore višeznačni su te ih je potrebno razmotriti iz različitih aspekata. Prije svega, moguće je usporediti funkcije trgovačkih centara i gradskih središta. Ono što odlikuje gradske centre jest intenzivno isprepletanje različitih funkcija i koncentracija središnjih funkcija poput uprave, poslovanja, trgovine, kulture, zabave i usluga (Maretić, 1996.). Premda trgovački centri često pokušavaju obuhvatiti mnoge funkcije koje su karakteristične za javne prostore gradova, oni ne mogu zamijeniti ni njihovu polifunkcionalnost ni identitetsku funkciju. Naime, dok su središta gradova mjesta od javnog značaja, trgovački centri pripadaju prostoru privatnog kapitala te stoga predstavljaju „pseudo-javni prostor“ (Horvat, 2007.), odnosno „polujavni prostor“ (Zlatar, 2011.; Stanić, 2013.), koji se naizgled doima javnim, a u biti predstavlja privatiziranu javnu sferu.

Utjecaj potrošačke kulture na restrukturiranje gradova moguće je analizirati i s obzirom na promjene koje doživljavaju gradska središta uslijed trenda suburbanizacije i decentralizacije trgovine, koji je od 1950-ih godina bio snažno prisutan u američkim, a potom i u mnogim europskim gradovima (Vresk, 2002.; Robertson, 2007.). Supermarketi i multifunkcionalni trgovački centri na periferiji grada s vremenom su odvlačili dio sadržaja i dinamike iz gradskih središta stvarajući iluziju urbanosti ondje gdje ona nije postojala i svodeći doživljaj urbane kulture na individualizirano iskustvo kupovine (Miles i Miles, 2004.). Prema istraživanjima u području urbane geografije i sociologije, privlačnost multifunkcionalnih trgovačkih centara kao mjesta za provođenje slobodnog vremena može dovesti do osiromašenja prodajne ponude u centru i smanjene privlačnosti središta grada (Hromadžić, 2008.; Thomas i Bromley, 2002.; Welterverden i Rietbergen, 2007.; Spierings, 2006.; Jakovčić, 2006.). Na opisane trendove posebno su osjetljiva središta manjih i srednjih gradova, u kojima promjena potrošačkih navika i sve veća popularnost trgovačko-poslovnih centara može ozbiljno ugroziti socijalnu i poslovnu dinamiku, zbog čega su mnoge lokalne zajednice suočene s mogućnošću gubljenja svoga trgovačkog i društvenog središta (Thomas i Bromley, 2002.). Gradski planeri stoga su prisiljeni razmišljati o tome kako vratiti trgovinu u središte grada, pri čemu mogu birati među različitim revitalizacijskim modelima kojima je cilj oživjeti središte grada kao središte potrošnje (Robertson, 1997.). Problematično je, međutim, što revitalizacija ${ }^{4}$ koja se zasniva na konzumerističkoj

\footnotetext{
4 Pojam urbane revitalizacije obuhvaća različite postupke i programe kojima je cilj ponovno unošenje života u cjelinu ili neki dio grada. Urbana revitalizacija zahtijeva kompleksno sagledavanje razloga degradacije fizičkog i socijalnog tkiva grada te najčešće uključuje niz ekonomskih, socijalnih i urbanističkih intervencija (prema Zlatar, 2013.:44).
} 
paradigmi može rezultirati gentrifikacijom, elitizacijom i komercijalizacijom gradskog središta, na štetu drugih značajki urbane kulture i gradskog identiteta.

Pojava novih multifunkcionalnih trgovačkih centara bila je jedan od najvidljivijih znakova transformacije postsocijalističkih gradova u Srednjoj i Istočnoj Europi (npr. Nagy, 2001.; Dimitrovska Andrews, 2005.; Uršič, 2009.). Koncentracija trgovačkih i poslovnih funkcija u predgrađima umjesto u središnjim dijelovima u mnogim je srednjoeuropskim gradovima ubrzala procese urbanog „prelijevanja“ i rezidencijalne suburbanizacije (Dimitrovska Andrews, 2005.). Osim toga, kao što pokazuje Uršič (2009.) na primjeru Ljubljane, uslijed otvaranja novih trgovačkih centara u gradskom središtu većinom su ostale trgovine luksuzne robe, ugostiteljski objekti, banke, hoteli i drugi sadržaji kojima lokacija u povijesnoj jezgri donosi „dodanu vrijednost“. Takvo restrukturiranje gradskog središta po mjeri potrošačkih praksi elita uzrokovalo je zatvaranje lokalnih trgovačkih i obrtničkih radnji te pojavu novog tipa socio-prostornog raslojavanja (Uršič, 2009.). Opisani trendovi nisu zaobišli ni hrvatske gradove. Primjerice, u Zagrebu je između 1994. i 2004. godine otvoren 31 kupovni centar ${ }^{5}$, dok je u samom središtu grada, na Ilici, zatvoreno preko 150 poslovnih prostora, od čega većinu čine trgovine (Jakovčić, 2006.:40). Premda pojava kupovnih centara na rubnim dijelovima grada nije jedini čimbenik koji je utjecao na zatvaranje malih trgovina u gradskoj jezgri, njihov razvoj dodatno je umanjio atraktivnost gradske jezgre kao odredišta za kupovinu (Jakovčić, 2006). ${ }^{6}$ S druge strane, pokušaji da se pojedini dijelovi gradske jezgre obnove izgradnjom multifunkcionalnih trgovačkih centara često su imali negativne posljedice, koje se očituju u uniformiranom izgledu grada te procesima privatizacije i komercijalizacije javnih prostora (Zlatar, 2013.; Zlatar, 2011.; Svirčić Gotovac, 2010.; Svirčić Gotovac, 2011.). Prema mišljenjima stručnjaka zaposlenih u gradskim upravama, jezgre hrvatskih gradova mogu se opisati kao mjesta koja su sve zanimljivija privatnim investitorima, koja se snažno komercijaliziraju, ali i kao mjesta u kojima dolazi do iseljavanja stanovništva (Mišetić, Miletić i Ursić, 2012.). U gradovima koji su ujedno turističke destinacije navedeni procesi mogu koincidirati s procesom turistifikacije ${ }^{7}$, koja može rezultirati pražnjenjem jez-

\footnotetext{
5 Pojam „kupovni centar“ ovdje se koristi kao sintetički naziv za nove prodajne oblike velikih površina, u koje se ubrajaju multifunkcionalni trgovački centri, hipermarketi, supermarketi, specijalizirani hipermarketi i trgovački centri-hipermarketi (prema Jakovčić i Rendulić, 2008.).

$\mathbf{6}$ Brojni čimbenici dovode do zatvaranja poslovnih prostora u povijesnim jezgrama, uključujući promjene u strukturi stanovništva, promjene potrošačkih navika i kupovne moći stanovnika, povećanu mobilnost te utjecaj novih tehnologija i promijenjenih obrazaca provođenja slobodnog vremena (Pacione, 2003., prema Jakovčić, 2006.). Osim ovih čimbenika, na zatvaranje poslovnih prostora na Ilici utjecao je i niz drugih faktora (npr. zapuštenost i dotrajalost urbane infrastrukture, loša prometna povezanost i nedovoljan broj parkirnih mjesta, neriješeni imovinsko-pravni odnosi) (Jakovčić, 2006.:38-45).

7 Proces turistifikacije odnosi se na transformaciju postojećih sadržaja u korist ugostiteljskoturističkih i komercijalnih sadržaja koji su prvenstveno namijenjeni posjetiteljima, a ne stalnim stanovnicima grada (Čaldarović, 1987.). Prema Jansen-Verbeke i Lievois (1999.), proces turistifikacije utječe na urbani sustav u cjelini mijenjajući njegovu fizičku, ekonomsku, socijalnu i kulturnu strukturu, intenzivirajući pojedine funkcije (npr. kupovinu) i istodobno potiskujući druge, tradicionalne urbane funkcije (npr. funkciju stalnog stanovanja).
} 
gre od stalnog stanovništva i njezinim pretvaranjem u „muzejsku kulisu zanimljivu za organizirane turističke obilaske“ (Hromadžić, 2008.:54). U Hrvatskoj su ovi procesi osobito vidljivi u povijesnim jezgrama Dubrovnika i Splita ${ }^{8}$, ali i u drugim gradovima čiji se ekonomski razvoj sve više zasniva na razvoju turizma.

\section{Razvoj trgovačkih centara i promjene u zadarskoj povijesnoj jezgri}

U razdoblju postsocijalističke tranzicije Zadar je od nekadašnjeg industrijskog i proizvodnog centra postao postindustrijski grad uslužnih djelatnosti, trgovine i turizma? Jedan od indikatora tih promjena pojava je kupovnih centara. Prvi specijalizirani hipermarket u Zadru otvoren je 1996. godine (Pevec) i od tada je moguce pratiti trend otvaranja hipermarketa i supermarketa, većinom na rubnim dijelovima grada u kojima su postojali prostorni uvjeti za izgradnju velikih trgovačkih centara (Jakovčić i Rendulić, 2008.). Prvi multifunkcionalni trgovački centar u Zadru, Trgovački centar Relja, otvoren je 2002. godine u istoimenoj gradskoj četvrti koja se nalazi nedaleko od povijesne jezgre i pored najfrekventnijih gradskih prometnica. Cijeli projekt dovršen je krajem 2008. godine kada je otvoren drugi dio centra, City Galleria, na 27,000 m2, koji je osim trgovačkih funkcija dobio i ostale sadržaje (kinodvorane, kafiće i klubove). Prema Jakovčić i Rendulić (2008.), u Zadru je do tada bilo otvoreno dvanaest kupovnih centara.

Premda u užoj gradskoj jezgri nisu postojali uvjeti za podizanje većeg trgovačkog centra, 2008. godine otvoren je manji centar, Callegro, koji je nastao preuređenjem nekadašnjeg kina Zadar u kompleks s trima kinodvoranama i jedanaest trgovina, koje su većinom imale ekskluzivniju ponudu (npr. dizajnerska odjeća, satovi, nakit). Gospodarska kriza i posljedični pad potrošnje doveli su do zatvaranja kina i centra Callegro (u lipnju 2010.), dok je u centru City Galleria bilo sve više zatvorenih poslovnih prostora. Unatoč tome krajem 2010. Zadar je dobio još jedan multifunkcionalni trgovački centar (Supernova) koji se s površinom od 38,000m² smjestio na krajnjem rubu gradskog područja, uz prometnicu koja povezuje grad sa zaleđem, zračnom lukom i autocestom.

Kada je riječ o razvoju trgovačkih centara kao novih prostora potrošnje, ali i provođenja slobodnog vremena, potrebno je ukazati na razvijenost njihovih socijalnih funkcija. Posredno se o razvoju socijalnih funkcija trgovačkih centara u Zadru može zaključivati na temelju rezultata anketnih ispitivanja posjetitelja (Jakovčić i Rendulić, 2008.; Šimić, 2010.). Rezultati anketnog upitnika provedenog 2007. godine na uzorku posjetitelja Trgovačkog centra Relja (Jakovčić i Rendulić, 2008.) pokazuju da preko 50\% posjetitelja u ovaj trgovački centar dolazi zbog drugih razloga osim

8 Jedan od pokazatelja ovih promjena opadanje je funkcije stalnog stanovanja. Povijesna jezgra Dubrovnika izgubila je u razdoblju od 1953. do 2001. godine 46,3\% stanovništva, a procjenjuje se da je 2006. imala svega 1241 stanovnika (Đukić i Jerković, 2008.:210).

9

9 Prema podacima koje donosi Razvojna strategija grada Zadra, u strukturi zaposlenog stanovništva sektor trgovine nalazi se na prvom mjestu s 20\% svih zaposlenih (SRGZ, 2013.:54). 
kupovine, odnosno zbog šetnje i rekreacije, zabave i druženja s obitelji i prijateljima (ukupno 55,8\%). Na razvijenost socijalnih funkcija trgovačkog centra ukazuje i visoki udio posjetitelja koji su u centar došli u pratnji prijatelja (44,7\%). Slične rezultate pokazalo je i anketno istraživanje provedeno 2010. godine (Šimić, 2010.).

Na koji je način proces decentralizacije i suburbanizacije trgovine povezan s promjenama u gradskoj jezgri? Prethodna istraživanja provedena u Zadru ne daju direktan odgovor na ovo pitanje. Međutim kao jedan od indikatora tih promjena može se uzeti opadanje interesa građana za odlazak u povijesnu jezgru radi odlaska u kupovinu, na što su prvi put ukazali rezultati kvalitativnog istraživanja provedenog 2006. godine (Čaldarović, 2009.). Zadarski građani koji su sudjelovali u tom istraživanju smatrali su problematičnim nekontrolirani razvoj i preveliki broj kupovnih centara (hipermarketa, supermarketa), kao i njihovu koncentraciju na ulazu u grad.

Rezultati anketnih ispitivanja (Šimić, 2010.; Tomić-Koludrović, Tonković, Zdravković, 2014.) također ukazuju na opadanje interesa građana za dolazak u povijesnu jezgru radi obavljanja kupovine. Prema rezultatima anketnog ispitivanja provedenog na Poluotoku 2011. godine (Tomić-Koludrović i sur., 2014.), najčešći su razlozi zbog kojih stanovnici drugih dijelova grada dolaze u povijesnu jezgru šetnja rivom (65,8\%), šetnja do Morskih orgulja i Pozdrava Suncu $(56,8 \%)$ i odlazak u kafiće (52,3\%), dok zbog kupovine u centar grada često dolazi 36,6\% ispitanika. Opadanje interesa građana za dolazak na Poluotok u zimskim mjesecima prepoznato je i u Strategiji razvoja grada Zadra kao jedan od najvažnijih problema gradske jezgre (SRGZ, 2013.). Među probleme Poluotoka Strategija također navodi odumiranje tradicijskih obrta, teškoće u poslovanju preostalih trgovaca i obrtnika, komercijalizaciju postojećih sadržaja te nepostojanje smjernica kojima bi se definirali sadržaji na pojedinim područjima Poluotoka. Međutim, pored ovdje navedenih problema, zadarsku povijesnu jezgru pogađa i proces depopulacije, što bi moglo predstavljati najveću prepreku njezinoj revitalizaciji. Naime, usporedba podataka dobivenih popisima stanovništva iz 2001. i 2011. godine pokazuje da je Poluotok u međupopisnom razdoblju izgubio 26,4\% populacije (Državni zavod za statistiku). Prema posljednjem popisu stanovništva, na području Poluotoka stalno stanuje 3650 stanovnika, svega 4,9\% od ukupne populacije grada Zadra. Podaci Državnog zavoda za statistiku također pokazuju kako je populacija Poluotoka u međupopisnom razdoblju postala u prosjeku starija te je udio stanovnika s navršenih 60 i više godina starosti porastao s $24,5 \%$ 2001. na 30,2\% 2011., dok je udio stanovnika do 20 godina u istom razdoblju smanjen s $21,6 \%$ na $15,5 \% .^{10}$

\section{Metode istraživanja}

Prethodna istraživanja koja su provedena u Zadru ukazala su na opadanje interesa građana za obavljanje kupovine u povijesnoj jezgri, ali i na to da Poluotok u cjelini nije izgubio svoju privlačnost kao prostor za šetnju i provođenje slobodnog vremena

10 Navedene je podatke za potrebe ovog rada ustupio Državni zavod za statistiku. 
(Čaldarović, 2009.; Šimić, 2010.; Tomić-Koludrović i sur., 2014.). Ovim istraživanjem htjelo se utvrditi stanje povijesne jezgre s obzirom na njezine komercijalne, poslovne i turističke funkcije. Kako bi se ustanovila zastupljenost komercijalnih i poslovnih sadržaja na Poluotoku, provedeno je terensko istraživanje kojim su popisani i kategorizirani poslovni prostori unutar Poluotoka. Popisivanje je provedeno za vrijeme turističke sezone, od 19. do 25. kolovoza 2013. godine. Za potrebe popisivanja izrađen je protokol koji je razlikovao pet tipova sadržaja (trgovački objekti, ugostiteljski objekti, zanatske radnje, financijske usluge, profesionalne i osobne usluge), koji su dodatno specificirani u potkategorije. ${ }^{11}$ Popisom nisu obuhvaćene udruge, neprofitne organizacije i javne ustanove. Dobiveni podaci nadopunjeni su podacima Turističke zajednice grada Zadra o smještajnim kapacitetima na prostoru Poluotoka kao najvažnijim indikatorom turistifikacije jezgre.

Prethodna anketna istraživanja ukazala su na učestalost korištenja različitih sadržaja unutar zadarske gradske jezgre (Šimić, 2010.; Tomić-Koludrović i sur., 2014.). S druge strane, ta istraživanja nisu omogućila stjecanje dubljeg uvida u stavove i mišljenja različitih tipova urbanih aktera o stanju Poluotoka. Zbog toga je u ovom istraživanju implementiran kvalitativni pristup. Kvalitativne metode osobito su prikladne onda kada je istraživanje usmjereno na razumijevanje značenja koje određene situacije imaju za sudionike u istraživanju te onda kada se istraživanjem nastoji razumjeti posebno okružje u kojem sudionici djeluju (Maxwell, 1996., prema Milas, 2005.:573). Korištenjem kvalitativnog pristupa nastojalo se dati odgovor na sljedeća pitanja: (1) kako pojedini tipovi aktera koji su poslovno i profesionalno vezani za povijesnu jezgru vide njezino trenutno stanje, (2) kako procjenjuju utjecaj procesa decentralizacije i suburbanizacije trgovine na socijalnu i poslovnu dinamiku povijesne jezgre te (3) kako vide glavne smjernice njezine revitalizacije. S obzirom na to da je ovaj dio istraživanja bio usmjeren prvenstveno na ispitivanje percepcije i značenja povijesne jezgre, a koja proizlaze iz specifičnosti osobnog i profesionalnog iskustva sudionika istraživanja, odabran je kvalitativni pristup koji je implementiran u vidu polustrukturiranih intervjua. U razdoblju od srpnja do studenog 2013. godine provedeno je ukupno dvadeset intervjua licem u lice s četirima skupinama urbanih aktera: (1) stručnjacima koji se bave prostorom (sociolozi, povjesničari umjetnosti, arhitekti, ekonomisti), (2) predstavnicima lokalne samouprave, (3) predstavnicima interesnih skupina koje djeluju u povijesnoj jezgri (trgovci, obrtnici, ugostitelji) i (4) predstavnicima civilnog društva. ${ }^{12}$ Sudionici istraživanja ciljano su izabrani prema svom profesionalnom djelovanju vezanom uz prostor povijesne jezgre te kako bi se obuhvatili najvažniji dionici procesa upravljanja prostorom. Premda stanovnici povijesne jezgre nisu ciljano obuhvaćeni, valja napomenuti da je četvrtina sudioni-

11 Prva verzija protokola izrađena je prema protokolu korištenom u istraživanju Jakovčić, 2006. Kategorije popisa nadopunjavale su se prema rezultatima terenskog istraživanja.

12 Navedena klasifikacija izvedena je iz obuhvatnije tipologije koju predlaže M. Bassand (2001., prema Zlatar, 2013., Svirčić Gotovac, 2010.). Prema ovom autoru, moguće je razlikovati četiri osnovna tipa urbanih aktera: ekonomski akteri (npr. predstavnici poduzeća, individualni poduzetnici, investitori), politički akteri (npr. lideri političkih stranaka, predstavnici vlasti), stručnjaci za prostor (npr. arhitekti, sociolozi, inženjeri), civilni akteri (stanovnici i civilne organizacije) (prema Zlatar, 2013.:80-83.). 
ka istraživanja u vrijeme prikupljanja podataka kontinuirano stanovala u povijesnoj jezgri, dok je dvoje sudionika na Poluotoku odraslo iako ondje više ne stanuju. ${ }^{13}$

S obzirom da se istraživanjem nastojalo kvalitativno, ali ipak sustavno ispitati mišljenja i stavove različitih tipova urbanih aktera, u istraživanju je korištena metoda polustrukturiranog intervjua. ${ }^{14}$ Svi su razgovori tonski snimani i naknadno transkribirani, a trajali su u prosjeku sat vremena. Protokol je sadržavao pitanja koja se mogu podijeliti u tri tematske cjeline. Prvi dio protokola odnosio se na procjenu trenutnog stanja zadarske povijesne jezgre i osvrt na promjene koje su se odvijale u tranzicijskome razdoblju. Drugi dio protokola bio je usmjeren na propitivanje mišljenja sugovornika o utjecaju trgovačkih centara na grad u cjelini te na povijesnu jezgru i njezinu socijalnu i poslovnu dinamiku. Posljednji dio razgovora bio je usredotočen na promišljanje mogućnosti revitalizacije Poluotoka te na razmatranje uloga pojedinih tipova aktera u procesu revitalizacije. Sa svim sudionicima istraživanja korišten je isti protokol. Polazište u kvalitativnoj analizi podataka predstavljale su teme kojima je definiran protokol istraživanja. Nakon iščitavanja transkripata uslijedio je proces kodiranja, a daljnja analiza obuhvaćala je grupiranje kodova u uže, a potom u šire teme (Creswell, 2007.). U analizi podataka komparirani su stavovi i mišljenja različitih tipova aktera.

Tablica 1.

Sudionici istraživanja

\begin{tabular}{|c|c|}
\hline Stručnjaci za prostor & $\mathbf{3}$ \\
\hline$-\quad$ ekonomisti & $\mathbf{1}$ \\
\hline$-\quad$ sociolozi & $\mathbf{1}$ \\
\hline$-\quad$ povjesničari umjetnosti & $\mathbf{2}$ \\
\hline$-\quad$ arhitekti & $\mathbf{3}$ \\
\hline Predstavnici interesnih skupina & $\mathbf{3}$ \\
\hline$-\quad$ obrtnici & $\mathbf{2}$ \\
\hline$-\quad$ trgovci & $\mathbf{3}$ \\
\hline$-\quad$ ugostitelji & $\mathbf{2}$ \\
\hline Predstavnici civilnog društva & \\
\hline Predstavnici lokalne samouprave &
\end{tabular}

\section{Komercijalne, poslovne i turističke funkcije Poluotoka}

Popisano je ukupno 615 poslovnih prostora, od čega je 551 prostor bio u funkciji, dok su 64 objekta u razdoblju popisivanja bila neaktivna, odnosno zatvorena. Od 551 poslovnog prostora 40,5\% odnosi se na trgovačke objekte (npr. trgovine odje-

$\mathbf{1 3}$ Istraživanje stambene funkcije zadarske povijesne jezgre, odnosno potreba i problema s kojima se susreću njezini stanovnici uvelike bi nadilazilo obuhvat ovog rada.

14 Za razliku od nestandardizirane forme dubinskog intervjua, metoda polustrukturiranog intervjua podrazumijeva da svi sudionici istraživanja odgovore na ista pitanja, što omogućuje sustavniji, ali još uvijek kvalitativni pristup problemu istraživanja (Denscombe, 2003.). 
će i obuće, suvenirnice, drogerije), 31,2\% na profesionalne i osobne usluge (npr. odvjetnički ured, geodetski ured, frizerski salon), 22,5\% na ugostiteljske objekte i objekte pripreme i posluživanja hrane (npr. restorani, kafići, objekti brze prehrane), $4,2 \%$ na zanatske radnje (npr. urar, bravar, krojač), dok se 1,6\% prostora odnosi na financijske usluge (npr. banke, mjenjačnice).

Grafički prikaz 1.

Zastupljenost pojedinih tipova sadržaja na Poluotoku

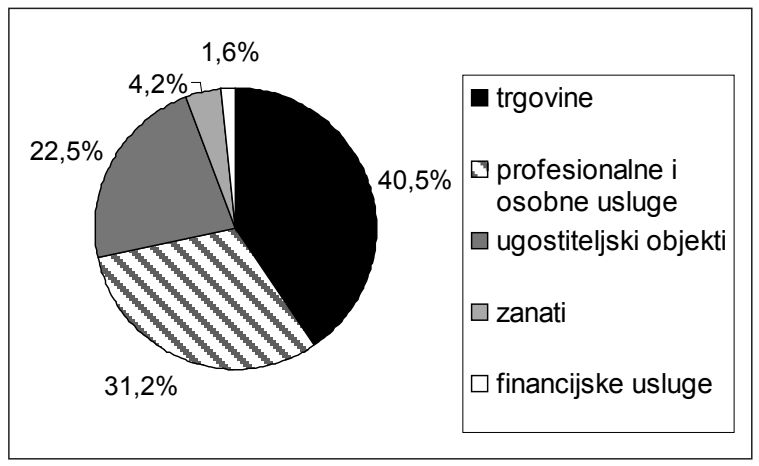

Trgovački objekti prevladavaju u nekoliko najfrekventnijih ulica na Poluotoku (npr. Široka ulica, Ulica plemića Borelli) te u blizini gradske tržnice i ribarnice. Među popisanim trgovačkim objektima trećina se odnosi na trgovine odjeće i obuće $(32,3 \%)$, međutim prevladavaju trgovine nemarkirane i sezonske robe, dok se većina popularnih modnih lanaca nalazi u trgovačkim centrima. Po zastupljenosti se također izdvajaju zlatarnice, suvenirnice i darovne trgovine, što pokazuje da se na Poluotoku koncentriraju specijalizirane trgovine namijenjene povremenim posjetiteljima i turistima.

Trgovački objekti slabo su zastupljeni u zonama pretežno stambene namjene, u kojima općenito ima malo poslovnih prostora, te u zonama u kojima prevladavaju ugostiteljski sadržaji. Ugostiteljski objekti, među kojima su kafići najzastupljenija kategorija (51,6\%), općenito na Poluotoku zauzimaju najfrekventnije ulice i trgove (npr. Trg Petra Zoranića, Narodni trg, Forum) te su najzastupljeniji tip sadržaja u blizini srednjih škola i Sveučilišta te u predjelu Varoš i na rivi, gdje čine skoro polovicu svih poslovnih prostora (48,8\%). Među profesionalnim i osobnim uslugama najzastupljeniji su odvjetnički uredi (26,1\%). Po brojnosti se također izdvajaju liječničke ordinacije, usluge projektiranja i nadzora građevinskih radova te putničke agencije.

Gubitak tradicijskog obrta u povijesnoj jezgri jedan je od problema na koje upozorava Strategija razvoja grada Zadra (SRGZ, 2013.). Popisivanje poslovnih prostora na Poluotoku pokazalo je kako su malobrojne zanatske radnje preostale u sporednim gradskim ulicama, u kojima prevladavaju manji poslovni prostori, često neprikladni za ugostiteljske i većinu ostalih komercijalnih sadržaja. U sporednim gradskim ulicama nalazi se i većina zatvorenih i neaktivnih poslovnih prostora, a njihova brojnost 
u vrijeme turističke sezone upućuje na zaključak kako potencijali gradske jezgre nisu najbolje iskorišteni.

Na središnjoj gradskoj osi, koja se proteže od Trga Petra Zoranića do Perivoja Gospe od Zdravlja te obuhvaća Narodni trg i Široku ulicu (Kalelargu), nalazi se približno jedna petina svih popisanih poslovnih prostora (20,2\%). Premda zastupljenost pojedinih tipova sadržaja (trgovačkih, ugostiteljskih itd.) ne odstupa značajno od prosjeka za cijelo područje obuhvaćeno popisom, u ovoj su zoni koncentrirane poslovne usluge (uredi), većinom na prvim katovima stambenih zgrada, te financijske usluge (banke i mjenjačnice koje se nalaze na najatraktivnijim prostorima na središnjoj gradskoj ulici), dok je u ljetnom razdoblju ovdje koncentrirana većina suvenirnica ${ }^{15}$ i objekata brze prehrane, što u cjelini ukazuje na procese cityzacije ${ }^{16}$ i turistifikacije povijesne jezgre, osobito njezinih najatraktivnijih dijelova.

Na trendove turistifikacije povijesne jezgre ukazuje i rastući broj smještajnih jedinica. Naime, prema podacima Turističke zajednice grada Zadra za 2013. godinu, na Poluotoku usluge smještaja pružaju 173 privatna iznajmljivača (ukupno 720 ležajeva), četiri hostela (ukupno 172 ležaja) i dva hotela (ukupno 82 ležaja), te je prema ovim podacima na Poluotoku približno tisuću ležajeva (974). Premda o ovome ne postoje precizniji podaci za ranija razdoblja, raspoloživi podaci Turističke zajednice za razdoblje od 2008. godine ukazuju na značajan porast smještajnih kapaciteta, osobito u privatnom smještaju, ${ }^{17}$ te se može zaključiti da je velik dio Poluotoka zahvaćen procesom apartmanizacije i posljedičnog gubitka funkcije stalnog stanovanja.

\section{Rezultati intervjua}

\subsection{Percepcija trenutnog stanja gradske jezgre}

Prije svega, može se primijetiti kako među različitim tipovima urbanih aktera, unatoč razlikama u profesionalnom podrijetlu, postoji suglasnost kada je riječ o pozitivnim aspektima promjena koje uočavaju na Poluotoku. Ponajprije, sugovornici ističu kako je Poluotok danas uređeniji i reprezentativniji, zahvaljujući projektima urbane obnove. Također, primjećuju kako Zadar postaje sve atraktivnije turističko središte, što se odražava na sadržaje u povijesnoj jezgri.

15 Ovdje valja napomenuti da su, osim suvenirnica koje su popisane u sklopu terenskog istraživanja, na odabranim lokacijama u povijesnoj jezgri postavljena 24 štanda za prodaju suvenira.

16 Cityzacija se može definirati kao proces funkcionalnih promjena gradske jezgre, koje se ogledaju u smanjenju stambene funkcije uz istodobnu koncentraciju poslovnih funkcija (Rogić, 1992.; Vresk, 2002.).

17 Prema evidenciji registriranih objekata privatnog smještaja, koju vodi Turistička zajednica grada Zadra, 2008. godine na Poluotoku je usluge smještaja pružalo 60 iznajmljivača te je u petogodišnjem razdoblju, do 2013. godine, njihov broj gotovo utrostručen. 
Kada je riječ o negativnim aspektima, zamjetan dio sugovornika navodi manjak komunalnog reda te sve izraženiju komercijalizaciju javnih površina, na što osobito upozoravaju stručnjaci. Ovdje se, međutim, mogu primijetiti i neke razlike među pojedinim tipovima aktera. Naime, dok ugostitelji ističu kako je povećan turistički promet pozitivno utjecao na poduzetnike koji su počeli više ulagati u povijesnu jezgru, dio stručnjaka upozorava kako se ta ulaganja odvijaju stihijski, bez strateških smjernica razvoja. Stručnjaci za prostor također ukazuju na nedovoljnu raznolikost ponude i nestajanje tradicijskog obrta te upozoravaju na nekontrolirani rast ugostiteljskih objekata i objekata brze prehrane, od kojih su mnogi zatvoreni izvan sezone.

Nadalje, u nizu iskaza ističe se primjedba kako najveću prijetnju po vitalnost gradske jezgre u budućnosti predstavlja postepeno iseljavanje stanovništva i posljedično opadanje funkcije stalnog stanovanja. Na ovaj problem podjednako ukazuju stručnjaci, predstavnici civilnog sektora, poduzetnici i predstavnici lokalne samouprave. Sudionici istraživanja pri tome ukazuju na nekoliko mogućih uzroka iseljavanja lokalnog stanovništva, uključujući neadekvatne stambene uvjete i prometnu nepristupačnost pojedinih dijelova Poluotoka, ali i promjene u turizmu koje su dovele do povećanog interesa za smještajnim kapacitetima u gradskoj jezgri.

Govoreći o problematičnim aspektima gradske jezgre, mnogi sudionici istraživanja primjećuju kako Poluotok posljednjih godina obilježava izrazita sezonalnost, pri čemu je ljeti prenapučen i posjetiteljima i sadržajima, dok se u zimskim mjesecima često stvara dojam „ispražnjenosti“ grada, a događanja su rijetka i slabo posjećena, što se može ilustrirati sljedećim iskazom:

„Stvara se jedan osjećaj nelagode, mislim da mogu bez pretjerivanja reći, kada prolazite kroz jednu takvu pustu ulicu. To posebno dolazi do izražaja izvan sezone, kada je Poluotok daleko pustiji i kada u osam sati navečer postane sve zamračeno, to postane nekakav grad duhova. Tim više što se dobar dio stanovnika iselio, u njihove stanove su se uselili uredi koji prestaju raditi u 5-6 sati popodne, i tada imate još manje razloga za dolazak na Poluotok" (arhitekt).

Komentirajući problem iseljavanja lokalnog stanovništva i dojam „ispražnjenosti“

\subsection{Posljedice izgradnje trgovačkih centara}

Većina sudionika istraživanja smatra da je pojava trgovačkih centara utjecala na promjene socijalno-prostornih odnosa na Poluotoku i gradu u cjelini. Premda većina sugovornika smatra da posljedice izgradnje trgovačkih i kupovnih centara nisu 
isključivo negativne, može se primijetiti da predstavnici civilnog društva i stručnjaci iskazuju kritičniji stav, dok su predstavnici interesnih skupina i lokalne samouprave češće ukazivali na pozitivne aspekte decentralizacije trgovačkih funkcija. Stručnjaci pri tome ističu kako su se trgovački i kupovni centri često gradili prema interesima investitora, bez strategije kojom bi se izgradnja regulirala.

Kada je riječ o utjecaju decentralizacije i suburbanizacije trgovine na promjene u gradskoj jezgri, većina sugovornika navodi da je došlo do postepenog opadanja posjećenosti Poluotoka u razdoblju izvan turističke sezone, što povezuju sa zatvaranjem malih trgovina i opadanjem raznolikosti trgovačke ponude. Kao što je primijetila jedna sugovornica:

„Početak kraja Poluotoka bila je Relja, otvaranje robnog centra na Relji. Bilo je tih centara i prije, ali početak kraja je bio robni centar Relja" (vlasnica trgovine).

Sugovornici starije i srednje generacije u razgovoru su se prisjetili kako je Poluotok bio središte trgovine i cjelokupnog gradskog života u vrijeme kada nisu postojali trgovački centri. Kako to ističe jedan sugovornik:

„Nekada je Poluotok bio centar, tu se događalo sve. Tu je Zadranka imala sve svoje prodavaone, moglo se kupiti sve, od igle do lokomotive. Poluotok je bio zanimljiv domaćim ljudima, a dolazak je bio kud i kamo veći“" (ekonomist).

Nadalje, većina sugovornika tvrdi da su sadržaji u gradskoj jezgri nedovoljno profilirani i pod snažnim utjecajem promjena na tržištu, što se odražava na opadanje kvalitete i raznovrsnosti ponude. Nekoliko sugovornika pri tome je upozorilo na probleme s kojima se suočavaju preostali stanovnici Poluotoka, posebno oni starije životne dobi. Primjerice, kako tvrdi članica jedne udruge građana, ujedno stanovnica povijesne jezgre:

„Izgleda smiješno, ali nemamo gdje kupiti žarulju i takve neke potrepštine. Recimo, nedostaju onakve trgovine kao što je bio Vice na Kalelargi. Kako nemam automobil, meni je vrlo komplicirano ići za Supernovu. Besplatan autobus je nedavno ukinut, a Poluotok je ionako loše prometno povezan."

Slaba prometna povezanost Poluotoka s ostatkom grada, nedovoljno razvijena mreža javnog prijevoza, nedostatan broj parkirnih mjesta te njihovo naplaćivanje također su, prema iskazima sugovornika, utjecali na smanjenje atraktivnosti gradske jezgre u usporedbi s kupovnim i trgovačkim centrima. Nadalje, dio sugovornika primjećuje da je šetnja trgovačkim centrom, čak i bez namjere da se obavi kupovina, postala jedan od uobičajenih načina provođenja slobodnog vremena, osobito među obiteljima s djecom. 
Tablica 2.

Pozitivni i negativni aspekti promjena u zadarskoj gradskoj jezgri: mišljenja sudionika istraživanja

\begin{tabular}{|c|c|c|}
\hline & $\begin{array}{l}\text { Promjene u gradskoj jezgri: } \\
\text { pozitivni aspekti }\end{array}$ & $\begin{array}{c}\text { Promjene u gradskoj jezgri: } \\
\text { negativni aspekti }\end{array}$ \\
\hline $\begin{array}{l}\text { Predstavnici } \\
\text { interesnih skupina } \\
\text { (ekonomski akteri) }\end{array}$ & $\begin{array}{l}\text { - Poluotok je postao reprezentativniji i } \\
\text { turistički atraktivniji } \\
\text { - povećan interes investitora za } \\
\text { ulaganje u jezgru } \\
\text { - novi hoteli i hosteli doprinose } \\
\text { dinamičnosti gradske jezgre }\end{array}$ & $\begin{array}{l}\text { - prometna izoliranost Poluotoka i } \\
\text { manjak parkirnih mjesta } \\
\text { - „ispražnjenost“ grada zimi } \\
\text { - izrazita sezonalnost stvara poteškoće } \\
\text { u poslovanju } \\
\text { - poskupljenje najma i usluga } \\
\text { - nedovoljna raznolikost sadržaja } \\
\text { - nestajanje tradicijskih zanata } \\
\text { - iseljavanje i starenje stanovništva }\end{array}$ \\
\hline $\begin{array}{l}\text { Predstavnici } \\
\text { lokalne } \\
\text { samouprave } \\
\text { (politički akteri) }\end{array}$ & $\begin{array}{l}\text { - Poluotok je postao reprezentativniji i } \\
\text { turistički atraktivniji } \\
\text { - razvoj turizma donosi nove sadržaje u } \\
\text { povijesnu jezgru (hoteli, hosteli itd.) } \\
\text { - obnovljeni su brojni javni prostori }\end{array}$ & $\begin{array}{l}\text { - prometna izoliranost Poluotoka i } \\
\text { manjak parkirnih mjesta } \\
\text { - iseljavanje i starenje stanovništva } \\
\text { - opadanje raznolikosti sadržaja } \\
\text { - nestajanje tradicijskih zanata } \\
\text { - izrazita sezonalnost }\end{array}$ \\
\hline $\begin{array}{l}\text { Predstavnici } \\
\text { civilnog društva } \\
\text { (civilni akteri) }\end{array}$ & $\begin{array}{l}\text { - povijesna jezgra dobila nove javne } \\
\text { prostore i sadržaje } \\
\text { - Poluotok postao reprezentativniji i } \\
\text { turistički atraktivniji }\end{array}$ & $\begin{array}{l}\text { - prometna izoliranost Poluotoka i } \\
\text { manjak parkirnih mjesta } \\
\text { - iseljavanje i starenje stanovništva } \\
\text { - nedostatak svijesti o potrebi očuvanja } \\
\text { povijesne baštine i javnih prostora } \\
\text { - nestajanje tradicijskih zanata } \\
\text { - opadanje raznolikosti sadržaja } \\
\text { - izrazita sezonalnost i „ispražnjenost“ } \\
\text { Poluotoka } \\
\text { - komercijalizacija javnih površina } \\
\text { - nedostatak komunalnog reda }\end{array}$ \\
\hline $\begin{array}{l}\text { Stručnjaci za } \\
\text { prostor } \\
\text { (stručni akteri) }\end{array}$ & $\begin{array}{l}\text { - Poluotok je postao reprezentativniji i } \\
\text { turistički atraktivniji } \\
\text { - obnova ranije zapuštenih prostora }\end{array}$ & $\begin{array}{l}\text { - prometna izoliranost Poluotoka i } \\
\text { manjak parkirnih mjesta } \\
\text { - iseljavanje stanovništva } \\
\text { - tendencija izmještanja sadržaja iz } \\
\text { gradske jezgre } \\
\text { - nedostatak svijesti o potrebi očuvanja } \\
\text { povijesne baštine i javnih prostora } \\
\text { - nestajanje tradicijskih zanata } \\
\text { - opadanje raznovrsnosti ponude } \\
\text { - otežan život lokalnog stanovništva } \\
\text { - ulaganja se odvijaju stihijski, bez } \\
\text { dugoročne strategije } \\
\text { - nekontrolirana apartmanizacija } \\
\text { - nekontrolirani rast ugostiteljskih } \\
\text { objekata } \\
\text { - manjak komunalnog reda } \\
\text { - komercijalizacija javnih površina } \\
\text { - gubi se genius loci }\end{array}$ \\
\hline
\end{tabular}




\subsection{Smjernice za revitalizaciju gradske jezgre}

Kada je riječ o mogućnostima revitalizacije povijesne jezgre, mišljenja su podijeljena, što je i razumljivo budući da se radi o najatraktivnijem dijelu grada u kojem se susreću, a nerijetko i sukobljavaju različite funkcije. Predstavnici različitih struka nerijetko su skloni parcijalnim rješenjima i mjerama. Primjerice, intervjuirani trgovci i obrtnici predlažu ukidanje pojedinih nameta i uvođenje olakšica poduzetnicima, osobito onima koji posluju tijekom cijele godine te subvencioniranje deficitarnih djelatnosti i tradicijskog obrta. Ipak, u većini dobivenih odgovora ističe se potreba za donošenjem strateškog plana razvoja Poluotoka koji bi odredio opće ciljeve revitalizacije gradske jezgre, u skladu s razvojnim odrednicama grada u cjelini. Taj prijedlog podjednako ističu stručnjaci kao i poduzetnici koji su poslovno vezani za prostor povijesne jezgre.

Odgovarajući na pitanja o mogućnosti revitalizacije trgovačkih funkcija gradske jezgre, sugovornici se slažu da su one bitne za vitalnost jezgre te da bi Poluotok trebao imati raznovrsnu trgovačku ponudu. Prema prijedlogu jednog arhitekta, na Poluotoku bi bilo poželjno revitalizirati središnju trgovačku ulicu, a cijeli Poluotok promovirati kao jedinstveno trgovačko središte. Međutim većina sugovornika ne vjeruje u mogućnost promjene potrošačkih navika i obnove interesa za Poluotok pored trgovačkih centara. Kao što ističe jedan član gradske uprave:

„Znate, pokušavalo se. Klizalište, 'Đir po gradu', imali smo razne aktivnosti, a ukinuta je i naknada parkinga u popodnevnim satima. Ali mislim da je najveći problem što su se ljudi u međuvremenu već naviknuli na ono što im pružaju trgovački centri."

Govoreći iz različitih perspektiva o razvoju turizma i njegovim utjecajima na povijesnu jezgru, većina sugovornika izrazila je stav da bi turističku djelatnost trebalo pažljivo planirati kako bi se atrakcijski potencijal grada povećao, a da se pri tome sačuva lokalni ambijent i suživot s potrebama lokalnog stanovništva. Trend daljnjeg pražnjenja Poluotoka od stalnog stanovništva prepoznaje se kao potencijalna prijetnja, međutim sugovornici većinom smatraju kako je malo vjerojatno da će taj trend u Zadru poprimiti one razmjere koji su vidljivi u Dubrovniku i Splitu.

Po pitanju utjecaja različitih tipova aktera na promjene u jezgri te o njihovim ulogama u revitalizaciji sudionici istraživanja gotovo se jednoglasno slažu da je najveći utjecaj lokalne samouprave, odnosno političkih aktera te da je gradska uprava najviše odgovorna za trenutno stanje gradske jezgre. Pri tome su lokalni poduzetnici skloni izražavanju nezadovoljstva zbog toga što grad, prema njihovoj procjeni, nedovoljno koristi mehanizme kojima raspolaže. Stručnjaci također smatraju poželjnom vidljiviju ulogu grada i gradskih službi, i to ponajprije u svrhu provođenja komunalnog reda i zaštite povijesne jezgre od devastacije. Dio sudionika istraživanja primjećuje, međutim, kako je gradska uprava često nemoćna pred pritiskom investitora te da se ključne promjene odvijaju neplanski, ovisno o zahtjevima tržišta i globalnim trendovima. 
Stručnjaci za prostor također ukazuju na slabu zastupljenost struke u odlučivanju o prostoru. Ta činjenica ne proizlazi toliko iz specifičnosti lokalne situacije, već se radi o karakteristici posttranzicijskoga prostornog planiranja u kojemu su stručni akteri često marginalizirani (Zlatar, 2013.). Akteri koji imaju malu pregovaračku moć, poput građanskih inicijativa i lokalnog stanovništva, također nisu posebno isticani kao oni od kojih se očekuje značajnija uloga u procesima odlučivanja te u provedbi budućih programa urbane obnove. Ovakvi nalazi u skladu su s rezultatima istraživanja drugih hrvatskih gradova, koja također ukazuju na percepciju građana i udruga civilnog društva kao relativno nemoćnih u usporedbi s političkim i ekonomskim akterima koji imaju najviše utjecaja u procedurama odlučivanja i realizaciji prostornih promjena (Zlatar, 2013.; Mišetić i sur., 2012.).

\section{Zaključna razmatranja}

Trgovački centar jedan je od simbola transformacije postsocijalističkog grada iz industrijskog grada proizvodnje u postindustrijski grad potrošnje. Taj se prijelaz ogleda u proizvodnji novih prostora za potrošnju koji dovode do složenih funkcionalnih promjena gradskih središta i periferije gradova. Na primjeru grada Zadra u ovom radu razmatrana je povezanost procesa decentralizacije i suburbanizacije trgovine s promjenama koje se odvijaju u povijesnoj gradskoj jezgri. Kako bi se utvrdilo trenutno stanje jezgre s obzirom na njezine komercijalne i poslovne funkcije, provedeno je terensko istraživanje kojim su popisani i kategorizirani poslovni prostori na prostoru zadarskog Poluotoka. Dobiveni podaci pokazali su kako na najatraktivnijim lokacijama na Poluotoku dolazi do koncentracije poslovnih i financijskih usluga, ugostiteljskih objekata i drugih sadržaja koji su prvenstveno namijenjeni turistima i povremenim posjetiteljima, što ukazuje na procese cityzacije i turistifikacije povijesne jezgre.

Kako bi se ispitalo kako različiti tipovi urbanih aktera koji su poslovno i profesionalno vezani za povijesnu jezgru vide njezino trenutno stanje i moguće smjernice revitalizacije, provedeno je kvalitativno istraživanje. Rezultati istraživanja pokazuju da su stručni i civilni akteri općenito više skloni zauzimanju kritičnog stava prema promjenama koje se odvijaju u povijesnoj jezgri. Primjerice, dok predstavnici interesnih skupina ukazuju na rastući atrakcijski potencijal gradske jezgre, stručnjaci upozoravaju na nedostatak strateških smjernica razvoja te na sve izraženiju tendenciju komercijalizacije javnih površina. Premda sudionici istraživanja smatraju da posljedice izgradnje trgovačkih centara nisu isključivo negativne, većina ih ukazuje na povezanost procesa decentralizacije trgovine s opadanjem posjećenosti Poluotoka i dojmom „ispražnjenosti“ grada u razdoblju izvan turističke sezone.

Opisano stanje zadarske povijesne jezgre, prema rezultatima provedenih istraživanja, nije uvjetovano isključivo lokalnim specifičnostima, već se može protumačiti kao posljedica tranzicijski uvjetovanih društvenih i prostornih promjena, koje, unatoč lokalnim razlikama, uzrokuju slične obrasce. Naime, umjesto cjelovite revitalizacije, povijesne jezgre mnogih hrvatskih gradova izložene su nekontroliranoj komercijalizaciji koja negira njihovu ulogu središta gradskog života i identiteta te 
proizvodi novi tip raslojavanja s obzirom na mogućnosti sudjelovanja u konzumerističkoj kulturi (Svirčić Gotovac, 2010.; Zlatar, 2011.). Neučinkovitost urbanih politika, deficit regulacije investicija u komercijalne, turističke i druge sadržaje te nedovoljna uključenost stručnih i civilnih aktera u procesima prostornog planiranja također ne doprinose cjelovitoj i sustavnoj obnovi povijesnih gradskih središta kao nezamjenjivog javnog dobra. Stoga bi budući programi revitalizacije povijesne jezgre u Zadru, ali i u drugim hrvatskim gradovima, trebali pokazivati više socijalne osjetljivosti i brinuti se o potrebama lokalnog stanovništva kako bi se zaustavili negativni trendovi, a prije svega depopulacija gradskih središta. U Hrvatskoj za sada izostaju strategije koje bi nastojale potaknuti obnovu malih i lokalno specifičnih trgovačkih i obrtničkih radnji, osobito tradicijskog obrta. S obzirom na važnost raznolikosti sadržaja za privlačnost i vitalnost gradskih središta (Uršič, 2009.; Welterverden i Rietbergen, 2007.; Thomas i Bromley, 2002.), poželjne su revitalizacijske strategije koje neće biti isključive prema manje profitabilnim sadržajima koji su važan dio gradskog identiteta, odnosno urbanosti jedne sredine. Kada je riječ o gradovima čiji su urbani resursi važan turistički atraktor, potreban je sustavan pristup obnovi gradskih središta kako bi se na najbolji način iskoristili povoljni učinci razvoja turizma, a spriječili ili zaustavili negativni trendovi koji umanjuju kvalitetu života lokalnog stanovništva, ali i atrakcijski potencijal grada.

\section{Literatura}

1. Creswell, J. W. (2007). Qualitative inquiry and research design. Choosing among five approaches. Thousand Oaks, London, New Delhi: Sage Publications.

2. Čaldarović, O. (2009). Urbano društvo na početku 21. stoljeća. Zagreb: Naklada Jesenski i Turk, Hrvatsko sociološko društvo.

3. Čaldarović, O. (1987). Suvremeno društvo i urbanizacija. Zagreb: Školska knjiga.

4. Čolić, S. (2008). Sociokulturni aspekti potrošnje, potrošačke kulture i društva. Društvena istraživanja, 17 (6): 953-973.

5. Denscombe, M. (2003). The Good Research Guide (for small-scale social research projects). Maidenhead: Open University Press.

6. Dimitrovska Andrews, K. (2005). Mastering the post-socialist city: Impacts on planning the built environment, u: Hamilton, I., Dimitrovska Andrews, K., Pichler-Milanović, N. (ur.): Transformation of cities in Central and Eastern Europe. Tokio/New York/Paris: United Nations University Press, 153-186.

7. Featherstone, M. (1991). Consumer culture and postmodernism. London, Newbury Park, New Delhi: Sage Publications.

8. Đukić, A. i Jerković, S. (2008). Neki suvremeni sociogeografski procesi u povijesnoj jezgri grada Dubrovnika. Geoadria, 13 (2): 207-225.

9. Horvat, S. (2007). Znakovi postmodernog grada. Zagreb: Naklada Jesenski i Turk.

10. Hromadžić, H. (2008). Konzumerizam. Potreba, životni stil, ideologija. Zagreb: Naklada Jesenski i Turk.

11. Jakovčić, M. (2006). Business Functions and Problem of Closure of Commercial Premises in Ilica Street in Zagreb. Hrvatski geografski glasnik, 68 (1): 27-50. 
12. Jakovčić, M. i Rendulić, I. (2008). Razvoj i funkcije kupovnih centara u Zadru. Geoadria, 13 (1) : 97-117.

13. Jansen-Verbeke, M. i Lievois, E. (1999). Analysing Heritage Resources for Urban Tourims in European Cities, u: Pearce, D. G. i Butler, R. (Ur.): Contemporary Issues in Tourism Development. London: Routledge.

14. Jayne, M. (2006). Cities and consumption. London: Routledge.

15. Lipovetsky, G. (2008). Paradoksalna sreća. Ogled o biperpotrošačkom društvu. Zagreb: Izdanja Antibarbarus.

16. Lukić, A. (2002). Socijalne funkcije trgovačko-poslovnog središta: primjer Centra Kaptol u Zagrebu. Hrvatski geografski glasnik 64: 73-94.

17. Lukić, A. i Jakovčić, M. (2004). Location and function of hypermarkets and shopping centers in Zagreb. Dela, 22: 39-54.

18. Maretić, M. (1996). Gradski centri. Zagreb: Školska knjiga.

19. Milas, G. (2005). Istraživačke metode u psihologiji i drugim društvenim znanostima. Jastrebarsko: Naklada slap.

20. Miles, S. i Miles M. (2004). Consuming Cities. Houndmills, Basingstoke, Hampshire, New York: Palgrave Macmillan.

21. Mišetić, A., Miletić, G. M. i Ursić, S. (2012). Vitalni gradovi. Pogled iz perspektive stručnjaka u gradskim upravama. Zagreb: Institut društvenih znanosti Ivo Pilar.

22. Nagy, E. (2001). Winners and losers in the transformation of city centre retailing in East Central Europe. European Urban and Regional Studies, 8 (4): 340-348.

23. Peračković, K. (2013). Osnovni pojmovi u sociologiji potrošnje, u: Čolić, S. (Ur.): Potrošačka kultura i konzumerizam. Zagreb: Institut društvenih znanosti Ivo Pilar, 25-45.

24. Robertson, K. A. (1997). Downtown retail revitalization: a review of American development strategies, Planning Perspectives, 12: 383-401.

25. Rogić, I. (1992). Periferijski puls u srcu od grada. Zagreb: Sociološko društvo Hrvatske.

26. Spierings, B. (2006). The Return of Regulation in the Shopping Landscape? Reflecting on the Persistent Power of City Centre Preservation within Shifting Retail Planning Ideologies. Tijdschrift voor Economische en Sociale Geografie, 97 (5): 602-609.

27. Stanić, S. (2013). Trgovački centar kao reprezent potrošačkoga društva, u: Čolić, S. (Ur.): Potrošačka kultura i konzumerizam. Zagreb: Institut društvenih znanosti Ivo Pilar, 127-147

28. Strategija razvoja grada Zadra (2013). Zadar: Razvojna agencija Zadarske županije.

29. Svirčić Gotovac, A. (2011). Aspekti ugroženosti javnih prostora, u: Čapo, J. i Gulin Zrnić, V. (Ur.): Mjesto, nemjesto. Interdisciplinarna promišljanja prostora $i$ kulture. Zagreb: Institut za etnologiju i folkloristiku, 303-316.

30. Svirčić Gotovac, A. (2010). Aktualni revitalizacijski i gentrifikacijski procesi na primjeru Zagreba. Sociologija i prostor, 48, 187 (2): 197-221.

31. Šimić, S. (2010). „Mjesto“ $i$ „nemjesto": primjer centra grada Zadra $i$ City Gallerie“. Diplomski rad. Odjel za sociologiju, Sveučilište u Zadru.

32. Thomas, C. J. i Bromley, R. D. F. (2002). The Changing Competitive Relationship between Small Town Centres and Out-of-town Retailing: Town Revival in South Wales. Urban Studies, 39 (4): 791-817. 
33. Tomić-Koludrović, I., Tonković, Ž. i Zdravković, Ž. (2014). Zadarska riva kao prostor urbanosti. Zadar: Sveučilište u Zadru.

34. Urry, J. (1995). Consuming places. London, New York: Routledge.

35. Uršič, M. (2009). Managing diversity in the post-socialist city - globalisation, spaces of consumption and exclusion of local urban cultures. Studia Universitatis Babeş-Bolyai, Sociologia, LIV, 1, 101-122.

36. Vresk, M. (2002). Grad $i$ urbanizacija. Osnove urbane geografije. Zagreb: Školska knjiga.

37. Welterverden, J. W. i Rietbergen, T. (2007). E-Shopping versus City Centre Shopping: the Role of Perceived City Centre Attractiveness, Tijdschrift voor Economische en Sociale Geografie, 98 (1): 68-85.

38. Zlatar, J. (2013). Urbane transformacije suvremenog Zagreba. Sociološka anali$z a$. Zagreb: Plejada/Institut za društvena istraživanja u Zagrebu.

39. Zlatar, J. (2011). Utjecaj trgovačkih centara (kao nemjesta) u Zagrebu na nestajanje javnog prostora, u: Čapo, J. i Gulin Zrnić, V. (Ur.): Mjesto, nemjesto. Interdisciplinarna promišljanja prostora i kulture. Zagreb: Institut za etnologiju i folkloristiku, 317-331.

\section{Prilog}

\section{Protokol intervjua}

1. Koje promjene uočavate na Poluotoku i možete li izdvojiti glavne uzroke tih promjena?

2. Koji su, po Vašem mišljenju, najvažniji pozitivni i negativni aspekti Poluotoka?

3. Koji tipovi aktera (ekonomski, politički, civilni, stručni) imaju najveći utjecaj na promjene u povijesnoj jezgri?

4. Kako su se trgovački centri razvijali u Zadru i što je najviše utjecalo na njihov razvoj?

5. Što mislite o utjecaju trgovačkih centara na grad u cjelini te na povijesnu jezgru i njezinu socijalnu i poslovnu dinamiku?

6. Jesu li trgovačke funkcije bitne za povijesnu jezgru grada? Zašto?

7. Ponekad se govori o tome da je potrebno regulirati i usmjeravati investicije, uključujući one u sektor trgovine i usluga. Što mislite o tome? Tko bi trebao usmjeravati te procese?

8. Prema Vašem mišljenju, što bi trebali biti glavni ciljevi i smjernice revitalizacije Poluotoka?

9. Kako vidite uloge različitih aktera (ekonomskih, političkih itd.) u revitalizaciji gradske jezgre? Koji akteri bi trebali biti najvažniji u tom procesu?

10. Postoji li još neki problem na koji do sada niste ukazali (u vezi s trgovačkim centrima, stanjem gradske jezgre i smjernicama za revitalizaciju)? 
Pregledni rad

\title{
Željka Tonković
}

Department of Sociology, University of Zadar, Zadar, Croatia

e-mail:zeljka.tonkovic@unizd.hr

\section{Shopping Centers and the Historic Town Core Transformations: The Case Study of Zadar}

\begin{abstract}
Shopping centers are a specific product and symbol of the consumer society and culture and their appearance one of the most visible signs of the post-socialist cities' transformation. The paper points to the connection between the process of decentralization and suburbanization of retailing and the transformation of the town center. The first objective of the study was to determine the current condition of the historic center of Zadar with respect to its commercial, business and tourist functions. In order to determine the structure of business establishments, fieldwork was conducted within the city center of Zadar. Another objective of the study was to examine how the actors professionally attached to the historic center perceived its current state and the main revitalization guidelines. For this purpose, qualitative research was conducted. Based on the research findings, the paper discusses the changes that take place in the historic center as well as general guidelines for its revitalization.
\end{abstract}

Key words: shopping centers, historic city center, public space, revitalization, Zadar. 